\title{
A GEOMETRICAL APPROACH TO RESEARCH INTO SIGNAL RECOGNITION IN VISUAL SYSTEMS OF HUMANS AND ANIMALS
}

\author{
Chingiz A. Izmailov, \\ Alexander M. Chernorizov \\ Lomonosov Moscow State University \\ Moscow
}

\begin{abstract}
In the paper an attempt is made to justify the importance of geometrical language (especially metric space models) for the description of visual perception processing. The tradition to use geometry for the description of psychophysiological processes goes back to a Newtonian color circle. At present there are many examples of such models, as well as of examples from other areas of mathematics. However, we want to justify a position, that geometrical language is not simply one of formal languages used for the description of visual perception phenomena. We'll try to represent it as the approach, which includes both the formal description of psychological phenomena and neurophysiological mechanisms, as well as experimental techniques of research into these phenomena and mechanisms.
\end{abstract}

Keywords: vector psychophysiology, categoriality of perception, perception of form and color, large (suprathreshold) interstimuli differences, multidimensional scaling, geometrical modeling of subjective perceptual spaces, spherical model of visual perception, neural modules (ensembles).

\section{Introduction}

Our work substantiates the proposition that the most appropriate methods of mathematical modeling in the visual processes are the construction, by multidimensional scaling methods, of a geometrical model of "subjective space," whose points represent stimuli detectable by the subject, and interpoint distances represent the "subjective differences" between stimuli. (Henceforth, to facilitate comparative analysis, the terms "subject," "subjective differences," and "subjective space" are used for both humans and experimental animals.) What distinguishes the geometric models of subjective spaces obtained in our works is that they are spherical. The spherical coordinates of the stimulus points are interpreted in the model as integral "output" characteristics of the "subject," and the 
Cartesian coordinates as a reflection of the contributions to the cognitive process made by the neurophysiological mechanisms (channels) that realize these subjective characteristics. Thus, the geometric modeling in our work is not simply a mathematical method for the formal representation of cognitive processes, but a special approach, a formal language that includes both cognitive phenomenology and the neurophysiological mechanisms that realize it. The main condition for implementing such an approach involves using a specific methodology for experimental research. It includes the measurement of large (suprathreshold) differences between all pairs of stimuli, analysis of the resulting matrix of pairwise differences by multidimensional scaling technique, and construction of a spherical model for discrimination among stimuli.

\section{Perception as the baseline cognitive process}

The authors of most post-behaviorist theories characterize the nature of cognitive processes by such concepts as "self-organization," "motivation," "focus," or "activity." These terms are used because cognitive processes cannot be reduced to a cause-effect mechanism, and involve purposeful behavior, with feedback and with the formulation of plans (cognitive maps, models, diagrams). This view is quite consistent with actual experience as well as with intellectual interpretation of this experience, and is supported by data from many experiments in the field of perception, thought, attention, and memory. The key concept for these ideas about the nature of cognitive processes is the notion of "categoriality." Cognitive processes are categorial, that is, they include "meaning," "sense," "intention," etc. Therefore, without understanding the processes of categorization, it is impossible to understand the nature of cognitive processes. Perceptual processes are baseline cognitive processes, and we can assume that research into such perceptual mechanisms as categorization can be used as the basis for understanding the nature of other cognitive processes. The present work concentrates on applying the "Man-Neuron-Model" approach (Sokolov, 1980; 1986; 2003) to the study of visual perception with the goal of establishing a connection between the data describing the mechanism of visual perception as psychophysical and neurophysiological functions and the data showing the categoriality of perception that does not fit into the framework of behaviorist methodology. 
The categoriality of perception means that the changes in the environment perceived by the organism (stimuli, events, influences) are characterized not only by physical properties, such as the intensity of an influence and its configuration (pattern in the distribution of intensity in time and space), but also by meaning. These changes provide the subject with various options for action, indicate what has already happened or should happen, have their individual character, and are included into a broader context, i.e., these influences contain something that goes beyond physical properties (Neisser, 1976).

The main problem, which is a stumbling block to constructing a theory of cognitive processes, is the following dilemma: is "meaning" a property of the stimulus (Gibson, 1979) or is it introduced into the learning process by the perceiving organism (Gregory, 1970)? At the beginning of its development, the cognitive approach to visual perception was represented primarily by "information theories," based on processes of converting the retinal image using different classification algorithms. It was assumed that detector mechanisms of the visual system distinguish specific excitation patterns on the retina. This information is then transmitted to the next, higher level of the visual system, where it is checked, screened, and combined with previously accumulated information. That is how the internal, subjective conception (image) of the influence of the environment is formed. Attempts to include cyclicity, the repetition of each cycle over time, into the model (Neisser, 1976; Ivanitsky, Strelets, \& Korsakov, 1984) with a phased development process involving memory, attention, and experience, change nothing, since the basic acts of perception are associated with the first stages of sensory analysis. But if perception is considered as an entire, multi-stage process, there is a single behavioral act in which all cognitive processes are interdependent (Shvyrkov \& Aleksandrov, 1973).

In this paper we propose a different approach to understanding the nature of visual perception, which combines the detector principle of information coding in the visual system with the principle of categorization. This does not require an appeal to processes of memory, learning, attention, or intelligence - i.e., the higher cognitive processes - and perception is considered as a separate and independent cognitive process. In this approach, the basic content of the act of perception is not the specification of the stimulus, i.e., recognizing "what" and "where" (Bongard, 1967) but involves the differentiation of stimuli and the de- 
tection of significant changes in the environment (Fomin, Sokolov, \& Vaitkyavichus, 1979; Izmailov \& Chernorizov, 2005). Specification (or identification) appears as a byproduct of the process of differentiation. In this way, significant changes in the environment are more important for the organism than are just noticeable changes anywhere near threshold. Accordingly, it is the data for analysis of suprathreshold differences between stimuli that form the basic material for our research.

\section{Measurement and analysis of large interstimulus differences}

\section{Subjective scaling}

Subjective evaluations of differences between stimuli represent the cumulative effect of the activity of all neural networks involved in encoding the physical characteristics of the stimulus and of decoding the electrophysiological pattern into a cognitive image. To understand the overall structure of the cognitive system, it is necessary to distinguish contributions of the individual links in this integral appraisal of interstimulus differences. Because the most important characteristic of the spherical model for stimulus discrimination is the simultaneous representation of both the psychological and neurophysiological characteristics of the cognitive process, the unification of methods for measuring interstimulus differences in psychological and neurophysiological experiments holds a special place in the description of our approach. Methods of measuring large supraliminal (suprathreshold) differences between stimuli in experiments with humans have a long tradition and are fully detailed in handbooks on scaling (Torgerson, 1958; Stevens, 1961). Electrophysiological techniques for such measurements are less well developed; they provide information on stimulus differentiation by large neural networks, recording evoked potentials in the cortex and in the subcortical brain structures of humans and animals, as well as by local area networks, recording extracellular and intracellular neuronal activity. At the foundation of these measurements is a method developed by researchers in our country for instantaneous exchange of stimuli (Bongard, 1955), which in the English-language literature is called stimuli exchange or the silent substitution method (Paulus, Homberg, Cuninghum, Halliday, \& Ronde, 1984). 


\section{The stimulus instant substitution method}

For electrophysiological measurements of large interstimulus differences, we developed a modified method for instantaneous (abrupt) stimulus exchange. An important feature of the method is the exchange of the stimulus for itself, when the reference stimulus and test stimulus are physically identical. In this case, a "null response" is considered an indicator of background activity, with respect to which the response of the cognitive system is evaluated as a non-null stimulus difference. Then, at the moment of (stimuli) exchange, a change in activity is also observed, and, as the data show, the greater increase of the difference between the stimuli evoked the greater increase of the response to their instantaneous abrupt exchange (Paulus et al., 1984; Zimachev, Shekhter, Sokolov, \& Izmailov, 1986; Chernorizov, 1995a; Izmailov, Isaichev, \& Shekhter, 1998; Izmailov, Korshunova, \& Sokolov, 2001; Izmailov et al., 2004). This fact served as the basis for using a series of test stimuli, which vary monotonically on both sides of the reference stimulus for the parameter selected by the researcher. The function that relates the magnitude of the electrophysiological response of the visual system to the magnitude of the differences between the reference and test stimuli forms a $\mathrm{V}$ shape, with its minimum in the areas of the minimum difference between the test and reference stimuli (Shapley, 1990; Zimachev et al., 1991). Such V-shaped functions were obtained for data based on recording of electroretinogram (ERG) in frog (Zimachev et al., 1986; 1991; Zimachev \& Chernorizov, 2001; Izmailov, Zimachev, Sokolov, \& Chernorizov, 2006), carp, and mollusc (Chernorizov, 1995a; 1999) (Fig. 1). The evoked visual cortical potentials, which we named evoked potentials of differences (EPD), were observed in animals and humans in response to instantaneous changes in visual stimuli of various kinds (light stimuli varying in colors ad luminance, lines of varying orientation, stimuli of various forms) (Paulus et al., 1984; Zimachev et al., 1986; Izmailov et al., 1998; 2001; 2004).

In the given set of stimuli each of them can be used as referential. The set of $\mathrm{V}$-shaped functions for all the reference stimuli forms a matrix of pairwise electrophysiological (objective) interstimulus differences. This matrix is analogous to the matrix of pairwise subjective differences (dissimilarities) that is obtained in psychophysical experiments with human subjects. In this way, the subjective evaluations of the differences and the electrophysiological measures of the differences are closely correlated (Izmailov et al., 2001). Thus, the transition from V-shaped differentia- 

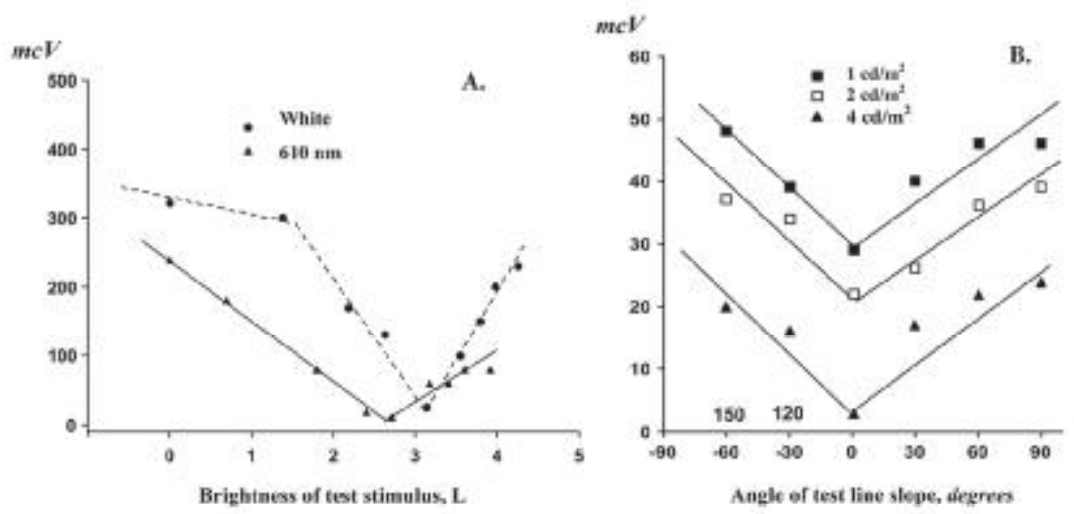

Figure 1. V-shaped functions characterizing distinguishing the brightness and orientation of the line by frog's eye (Zimachev et al., 1986; Izmailov et al., 2006; Izmailov \& Zimachev, 2007). Graphs represent the change of b-wave amplitude of frog ERG (vertical axis) in response to increasing differences in brightness (abscissa) between a fixed reference stimulus (white or red, $610 \mathrm{~nm}$ ) and varying in brightness test stimulus (abscissa).

A. Graphs represent data for two reference stimuli - white (triangles) and red (dots) with a brightness values $23 \mathrm{~cd} / \mathrm{m}^{2}$ and $15 \mathrm{~cd} / \mathrm{m}^{2}$, respectively. For simplicity here and below graphs are approximated by linear functions, although most often V-shaped functions of discrimination have a nonlinear form (Izmailov \& Zimachev, 2007; 2009).

B. Graphs represent the data for the bimodal changes between the reference stimulus (horizontally oriented line with brightness $4 \mathrm{~cd} / \mathrm{m}^{2}$ ) and a series of test lines simultaneously changing in brightness and orientation. Abscissa represents the differences between the reference and test stimuli varying in orientation from $0^{\circ}$ to $150^{\circ}$ at three levels of brightness (triangles, dots and squares). The values of the orientation of $120^{\circ}$ and $150^{\circ}$ relative to the horizontal are represented as the corresponding values $60^{\circ}$ and $30^{\circ}$ to demonstrate the symmetry of the responses of the retina to the difference in orientation, regardless of the direction of rotation of the line. Adding to the difference in orientation between the stimuli, luminance difference leads to a systematic shift of $\mathrm{V}$-shaped function of discrimination along vertical axis as a result of summation of responses of the retina to the double (in orientation and brightness) change in the stimulus (Izmailov \& Zimachev, 2007). 
tion functions to the matrix of pairwise differences between stimuli in psychophysical and neurophysiological experiments ensures the unity of experimental methods for obtaining initial data - both from the standpoint of content, by studying different cognitive systems, and also from the standpoint of comparing the experimental data from studies of humans and animals.

\section{Analysis of the matrices of interstimulus subjective or objective differences by the method \\ of multidimensional scaling}

An additional feature of our approach is the use of the multidimensional scaling method to construct a geometrical model of stimulus differentiation (Torgerson, 1958; Shepard, 1962; Kruskal, 1964). Here a key role is played by the concept that underlies the method of multidimensional scaling, that of representing the differences between stimuli as geometrical distances. The dimension $m$ of this space is determined by the number of positive eigen values of the matrix of scalar products, calculated from the original matrix of interstimulus distances. The factorization of the matrix of scalar products gives the values of the coordinates of a point on each of the $m$ axes. This solution is based on the validity of the source data, comprising a matrix of pairwise differences. However, experimental data are always accompanied by measurement errors, both random and systematic. These errors occur in the solution obtained, in part, from the $m$ axes, and so the challenge is to identify the minimum necessary dimension $k$ of the stimulus differentiation space. Further, since the space of the stimulus points is derived only from the interpoint distances, it is random with respect to the starting position of the axes' coordinates and their orthogonal rotation. Various options have been developed for determining the minimum dimension and unique coordinate system. The best known are algorithms based on the ideas of Shepard and Kruskal (Shepard, 1962; Kruskal, 1964).

\section{Determination of the Spatial Dimension of Discriminated Stimuli}

In our work, we use algorithms based on a spherical model of differentiation. A detailed description of these algorithms is given in the works cited (Izmailov, 1980; Sokolov \& Izmailov, 1984). Our solution is based not only on formal, but also on substantive conditions: 
1. The relation between the interpoint distances and the interstimulus differences must satisfy the requirement of global linearity (Shepard \& Carroll, 1966; Shepard, 1987). This condition is associated with the isotropy of subjective space, and is estimated by the value of linear correlation coefficient or Kruskal stress (Izmailov, 1980; Izmailov \& Sokolov, 1978).

2. The resulting space is centered so that the beginning of the coordinate system is located at the geometric center of the configuration of points, for which the variation of lengths of the radius vectors of the points would be minimal (Izmailov, 1980; Izmailov \& Sokolov, 1978).

3. The variability of the radii is estimated as the ratio of the standard deviation of the radius vectors to the mean radius (coefficient of variation), expressed as a percentage.

4. In accordance with the concept of two-channel coding of each attribute in the visual system (Sokolov \& Izmailov, 1988), coordinates of the stimulus point for each pair of axes in Euclidean space reflect the contribution of the activity of two opponent neurophysiological channels in the differentiation of stimuli.

5. The spherical coordinates of the stimulus points in the plane of these opponent coordinates should reflect the cognitive component of the process of stimulus differentiation. Satisfying this condition involves integrating, within the geometrical model, cognitive phenomenology with the characteristics of the neurophysiological mechanisms of the visual system of humans and animals.

\section{The Spherical Model of Visual Stimuli Discrimination}

In a series of experiments using a variety of visual stimuli, we obtained estimates of large interstimulus differences, which were analyzed by different methods of multidimensional scaling. In all cases, when the stimuli were varied by one subjective variable, analysis of the matrix of pairwise differences led to a spherical model of discrimination, similar to the one that was designed to encode perceived brightness of light stimulus (Fomin et al., 1979). In particular, this model was obtained through 
the study of human achromatic vision using disk-annulus stimuli in disk-ring form (Izmailov, 1980; Izmailov \& Sokolov, 1991; Izmailov et al., 2001). It was shown that to meet the condition of linearity between the initial estimates of differences and interpoint distances (Shepard \& Carroll, 1966), a two-dimensional Euclidean space was required (Fig. 2 A). This result is consistent with the two-dimensional geometrical model of achromatic colors constructed by P. Heggelund (1974) on the basis of experiments with similar stimuli. However, our solution has significant differences from Heggelund's two-dimensional model. The stimulus points in the spherical model do not fill the entire plane uniformly, but form a curved trajectory in the shape of an arc. At one end of this arc are "black" stimuli, with a minimally bright disk and a maximally bright annulus. At the other end are the brightest stimuli, in inverse proportion to the luminance of the disk and the annulus. All the intermediate points also correspond to the luminance ratio of the disk and annulus (Fig. $2 \mathrm{~A}$ ). To test the sphericity of the obtained configuration of pointsstimuli, a procedure was used that determines the deviation (coefficient of variation of radii) of the experimental data from the equation for a (two-dimensional) sphere:

$$
Y_{1 i}^{2}+Y_{2 i}^{2}=R_{i}^{2}
$$

The value of the coefficient of variation varies from $7-12 \%$ for various subjects. This shows that the stimuli actually form a circular trajectory on the plane. But unlike the model of Fomin et al. (1979) where a spherical metric is proposed to measure differences between the stimuli, our data show that estimates of perceived differences are described by a Euclidean metric (Izmailov, 1980; 1981; Izmailov \& Sokolov, 1978; 1991; Sokolov \& Izmailov, 1984):

$$
d_{i j}^{2}=\sum_{k=1}^{n}\left(X_{k i}-X_{k j}\right)^{2}
$$

Thus, the spherical model of stimulus differentiation proposed in our work is described by equations [1] and [2].

The circular trajectory of point localization means that a spherical coordinate acts as a subjective sensory variable: here - the horizontal angle formed by the stimulus point on the plane. This conclusion is easily verified by plotting the spherical coordinates of the points against 


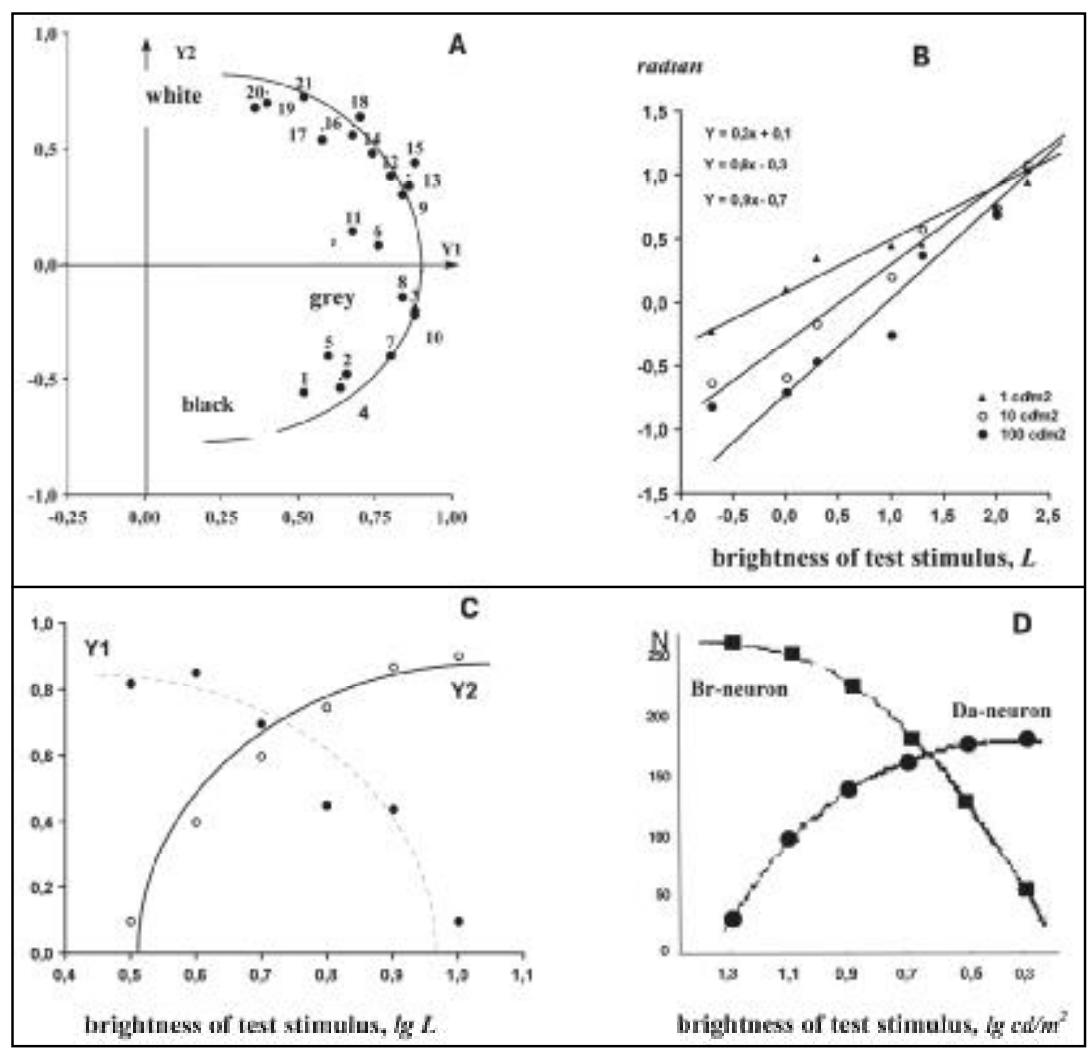

Figure 2. Spherical model of human achromatic vision

(Sokolov \& Izmailov, 1984; 1991).

A. The two-dimensional space of distinction 21 stimuli in the form of disc-ring. Central disc varied on seven levels of brightness $\left(0.2,1,2,10,20,100\right.$ and $\left.200 \mathrm{~cd} / \mathrm{m}^{2}\right)$, and the surrounding background - on three levels of brightness $\left(1,10\right.$ and $\left.100 \mathrm{~cd} / \mathrm{m}^{2}\right)$. The number beside the point (1-7) indicates the order of changing in experiments the brightness of the disk from the minimum value $0.2 \mathrm{~cd} / \mathrm{m}^{2}$ at maximum brightness $\left(100 \mathrm{~cd} / \mathrm{m}^{2}\right)$ of the background (= number 1$)$ to maximum value $200 \mathrm{~cd} / \mathrm{m}^{2}$ with a minimum bright $\left(1 \mathrm{~cd} / \mathrm{m}^{2}\right)$ of the background (= number 21$)$. The distribution of points-stimuli on the plane discovers a circular configuration.

B. The psychophysical function of luminance perception for seven stimuli varying in brightness of the disk at three fixed levels of the background brightness. Abscissa re- 
the brightness of the stimuli (Izmailov, 1982; 1995; Sokolov \& Izmailov, 2006) (Fig. 2 B). Such graphs show that the resulting function corresponds to the standard logarithmic brightness function, derived firstly by G. Fechner and later confirmed by a number of psychophysical experiments (Hartridge, 1950; Stevens, 1961).

According to the generalized spherical model of sensory systems proposed in the work of Fomin et al. (1979) the two axes, Y1 and Y2, of the Cartesian coordinate system represent the neural network including two channels that are formed by the brightness $(\mathrm{Br})$ - and darkness (Da) - neurons of the visual system (Chernorizov, 1995a; 1995b; 2008; Chernorizov \& Sokolov, 2001; Latanov, Leonova, Evtikhin, \& Sokolov, 1997). The channels are linked in a reciprocal relationship, so that when $\mathrm{Br}$-channel in the network is activated more with greater light intensity (axis Y1), then the Da-channel (axis Y2) is activated less, and vice versa (Fig. 2 C, D) Thus the total activity of the channels, represented by the size of the circle's radius, remains constant, as expressed by the equation for the sphere (cf. equation [1]). One example of such a reciprocal system of visual neurons is a system of ON- and OFF-neurons in the visual cortex of cat (Poggio, Baker, Lamarre, \& Sanseverino, 1969; Jung, 1973).

The results of modeling human achromatic vision fully correspond with the results of experiments on brightness discrimination with different animals (Chernorizov, 1999; 2005; Izmailov et al., 2006; Chernorizov, Zimachev, Shekhter, \& Garusev, 2007). For example, in experiments with frogs or molluscs the overall response of the retina (electroretinogram) to instantaneous change of stimuli was registered, with the subsequent construction of a V-shaped differentiation function (Chernorizov, 1999;

presents the values of stimuli brightness in logarithmic units, and the vertical axis the spherical coordinates of points on the plane Y1Y2 (in radians), characterizing the perceived brightness (lightness) of the stimulus.

C. Diagrams describing the neurophysiological interpretation of the Cartesian axes in the spherical model of achromatic vision as light $(\mathrm{Br})$ and dark $(\mathrm{Da})$ channels of the visual system. Abscissa: the brightness of the stimuli, and the ordinate - normalized values of Cartesian coordinates for the stimuli located in the upper right quadrant of the plane Y1Y2.

D. Responses of $\mathrm{Br}$ - and Da-neurons in the visual cortex of cats to the flashes of white light of different intensities (Poggio, 1969). 

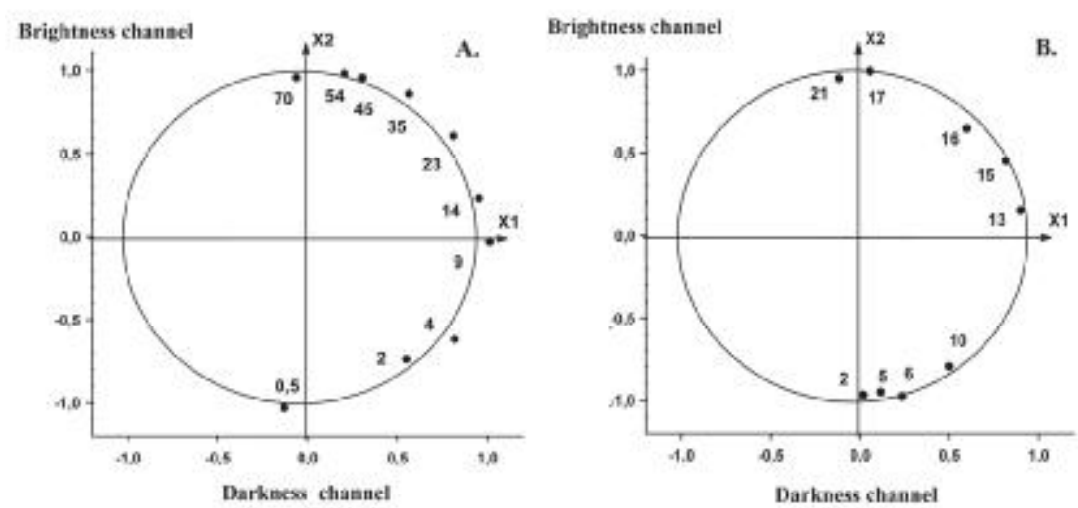

Figure 3. Location stimuli of different brightness in two-dimensional spherical model derived from analysis by multidimensional scaling matrix amplitudes of ERG b-wave of frog (A) (Izmailov et al., 2006) and matrix amplitudes of component N85 in rabbit evoked potential of discrimination (B) (Polansky et al., 2008 ). Responses of frog retina (ERG) and visual cortex of rabbit (evoked potentials) recorded in response to instantaneous change of stimuli with different brightness. Values of stimuli brightness $\left(\mathrm{cd} / \mathrm{m}^{2}\right)$ are listed next to the appropriate points. The figures 2 and 3 demonstrate that the achromatic vision of human (Fig. 2) and animals (Fig. 3) may be described by just the same spherical model of discrimination.

Zimachev \& Chernorizov, 2001; Izmailov et al., 2006). Analogous experiments were conducted on rabbits where the abovementioned visual evoked potentials of differentiation were studied (Polyansky, Sokolov, \& Evtikhin, 2000; Polyansky, Alymkulov, Sokolov, \& Radzievskaya, 2008). The matrices of pairwise differences based on the V-shaped functions were analyzed using multidimensional scaling, as it was in experiments with humans. It was found that the geometrical model of brightness discrimination in invertebrates (Chernorizov, 1999; 2006; 2007; 2010), in lower vertebrates (Izmailov \& Sokolov, 1991; Paramei \& Chernorizov, 1991; Chernorizov, 1995a; 1995b; 1999; Izmailov et al., 2006) and mammals (Latanov et al., 1997; Polyansky et al., 2000; Polyansky et al., 2008) takes the form of a two-dimensional sphere (Fig. 3). This means that exactly the same two-channel mechanism for differentiating light intensity operates in the visual system of humans and animals, as described by the spherical model of stimulus discrimination (Sokolov \& Izmailov, 1988; Izmailov \& Sokolov, 1991; Chernorizov, 2008). 
Analogous results are obtained from multidimensional scaling of subjective estimates of supraliminal differences in orientation between lines of fixed brightness (Izmailov \& Sokolov, 1990; Izmailov et al., 2004). Stimulus points (lines of different orientation) are located along a circle in two-dimensional Euclidean space (Fig. 4 A). Thus the subjectively perceived orientation is represented by the spherical coordinate
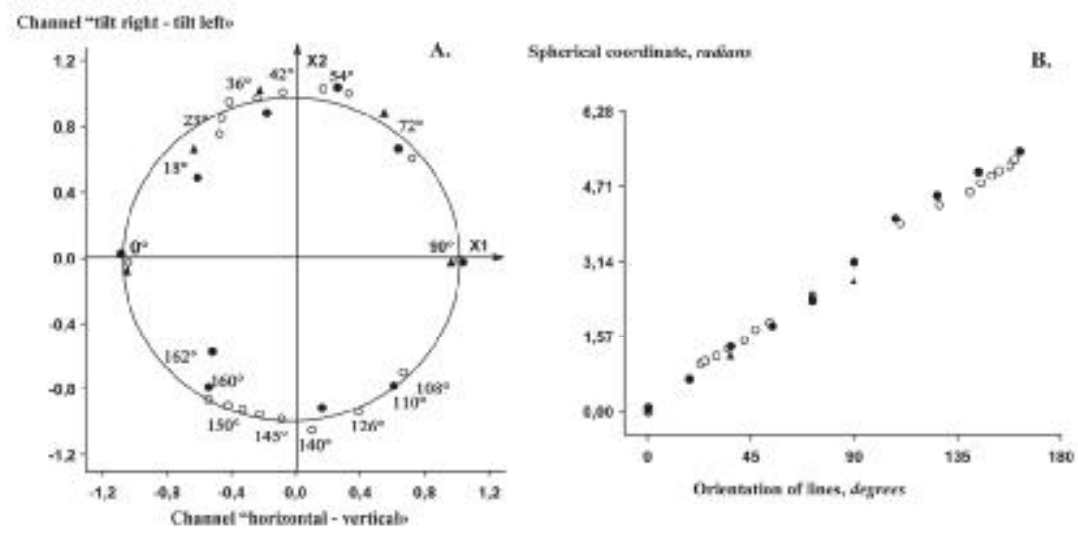

Figure 4. The subjective two-dimensional space of perception orientations of lines, constructed according to the psychophysical (subjective ranking) and electrophysiological (evoked potentials) estimates of differences between lines with different slope.

Designations: open circles - psychophysical data from work by Izmailov and Sokolov (1990) (18 lines), black circles - psychophysical data from work by Izmailov et al. (2004) (10 lines), black triangles - two-dimensional space based on the registration of evoked potentials (Izmailov et al., 2004). Nearly every point on the graphs in Fig. $4 \mathrm{~A}$ the values of the angle of inclination of the stimulus relative to the horizon (in degrees) are indicated.

A. Two Cartesian axes are interpreted as two opponent neural channels: "vertical horizontal" and of "slope to the right - slope to the left." Horizontal angle of each point (clockwise from the negative direction of axis X1) characterizes the subjective evaluation of orientation.

B. Psychophysical function for perception orientation lines, constructed according to the data in Fig. 4 A. Abscissa: the values of orientation angle of the line (in degrees), and the vertical axis: the spherical coordinates of the point-stimulus, measured as the horizontal angle of the point (in radians). For details see the text. 
of the stimulus points, and the two Cartesian axes represent two opposing channels: "vertical-horizontal" and "tilt to the right-tilt to the left" (Shelepin, 1981). Experiments recording the retinal activity of the frog (Izmailov \& Zimachev, 2008) and the evoked potentials of the visual cortex of the rabbit (Polyansky et al., 2008) and human (Izmailov et al., 2004) (Fig. 4 B) in response to instantaneous changes of lines of differing orientation, corresponded to the spherical model of stimulus differentiation.

\section{A two-channel neural network}

\section{as a basic mechanism (module) of the visual system}

The similarity between two-dimensional spherical models for light intensity and orientation of lines could be explained from the standpoint of the separation of stimuli into the subjectively simple and the subjectively complex ones, according to the traditional divisions of sensory and perceptual aspects of perception. However, researchers have already confronted the problem of a priori designation of simplicity or complexity of a stimulus. We also discovered that not only light intensity and the orientation of lines, but also more complex stimuli - such as surface color (Izmailov, 1995), or a figure consisting of two lines (Izmailov \& Sokolov, 1990), or three lines converging upon a single vertex (corners, forks, arrows, T-shaped figures) (Izmailov et al., 2008) - can also be represented in geometric terms by a spherical model of signal discrimination and, accordingly, in terms of the two-channel neural network.

Based on our data, we can conclude that there are two states of the visual environment which constitute the basis of visual stimulus perception. On the one hand, there is the intensity and spectral composition of light, i.e., the energy characteristics of the stimulus. On the other, there are the boundaries dividing the visual field into localized parts. This dichotomy is quite consistent with the data from ERG recordings of the vertebrate retina with homogeneous light stimuli and patterns in the form of a one-dimensional or two-dimensional lattice with different spatial frequencies (Maffei et al., 1985; 1990). In the latter case, the terminology used for electroretinogram changes is "PERG," which refers to the response of the retina to the formed stimulus (pattern). Retrograde degeneration of retinal ganglion cells caused by section of the optic nerve leaves the ERG intact, whereas the PERG is reduced to the 
level of noise. These data allow us to conclude that the retinal ganglion cells play an essential role in the generation of the PERG. The data from intracellular recording of cellular activity in the retina of a monkey in response to stimuli that are homogeneous (in brightness) and structured (in configuration) (Hess, 1984; Maffei et al., 1990) confirm the thesis that the PERG is generated primarily by neurons of the inner plexiform layer, whereas the ERG reflects the activity of receptors and cells of the outer plexiform layer. Analogous results were obtained in our own studies of the frog retina (Izmailov \& Zimachev, 2008). These findings allow us to consider the division of cells into ON and OFF types as a fundamental neurophysiological characteristic of the visual system, conditioned not only by energy opposition arising from the duality of visual stimulation (light / dark), but also by the configurational opposition (homogeneity / heterogeneity).

The synthesis we propose is made concrete by a visual mechanism demonstrating a spherical model of stimulus discrimination. The identification of a mechanism that similarly encodes the energy and configuration features of the light environment supports the hypothesis about the modular organization of visual perception, where the modules are not defined by lists of physical or subjective characteristics, but by describing each of them separately. Examples of this modular principle are systems analogous to Guzman's "nodes" (Winston, 1974) or to the elements of a written alphabet. This approach to the organization of visual perception (Julesz, 1984; Biederman, 1995) did not gain acceptance, not only because of the vagueness of the "module" as a subjective unit, but also due to the inability to link it with a specific neural network. A spherical model of stimulus discrimination can eliminate these difficulties, because its most characteristic feature is that it encompasses both a mechanism for neurophysiological coding of stimuli in the visual system (Cartesian coordinates), and a mechanism for decoding a neurophysiological code into the subjective features of the visual image (spherical coordinates).

This makes it possible to assert the two-channel module as the basic mechanism by which the visual system can represent subjective variables (Sokolov \& Izmailov, 1983; 1988; 2006; Izmailov et al., 1998) (Fig. 5). The main distinguishing feature of this module is that it is not directly connected either with an encoded stimulus, or with a decoded sensory response. It is a kind of structure that can be used to convert any stimulus into an arbitrary "subjective" feature. For example, the vibration fre- 
quency of air or liquid can be decoded into color, and the frequency of electromagnetic oscillations into the orientation of a line. The specificity of the stimulus is determined by the structure of the two-channel module's input unit and the content of its code; its "subjective" value is determined by the correlation of the activity of the two opposing channels of the "two-dimensional module" and the special structure of the output unit. One advantage of this module is that specification of a subjectively simple attribute and its associated stimulus is not provided a priori, but is produced a posteriori, by identifying the spherical structure of these distinctions. Only if the matrix of pairwise differences between the stimuli is consistent with a spherical model of discrimination, is it possible to conclude that these stimuli are being decoded by a two-channel neural network of the visual system, in a simple (one-dimensional) subjective mode.

\section{A three-stage model of the visual system}

The universal nature of the two-channel module makes it possible to combine the most varied input and output structures of the visual system, and the corresponding neural networks sufficient to obtain information about the external environment. Each network will contain three links: an input receptor link, a set of two-channel modules, and an output detector link (Sokolov \& Izmailov, 1983; 1988) (Fig. 5). Corresponding to the network structure, three phases, or three stages of processing sensory information in the visual system of humans and animals are formulated.

\section{Receptors and "quasi-receptors" of the visual system}

Theoretically, the input link of the three-stage neural network, which forms the neurophysiological basis of perception, could consist of any receptors. In particular, the visual system is based on photoreceptors, which are the input structures of the neural networks that convert the intensity and frequency of electromagnetic radiation into brightness and color. However, the detection of lines, edges, and boundaries by the vertebrate visual system is considered by many researchers to be one of the key characteristics in the neural network's pattern recognition (Lindslay \& Norman, 1972; Winston, 1978; Shevelev et al., 1999; Izmailov et al., 


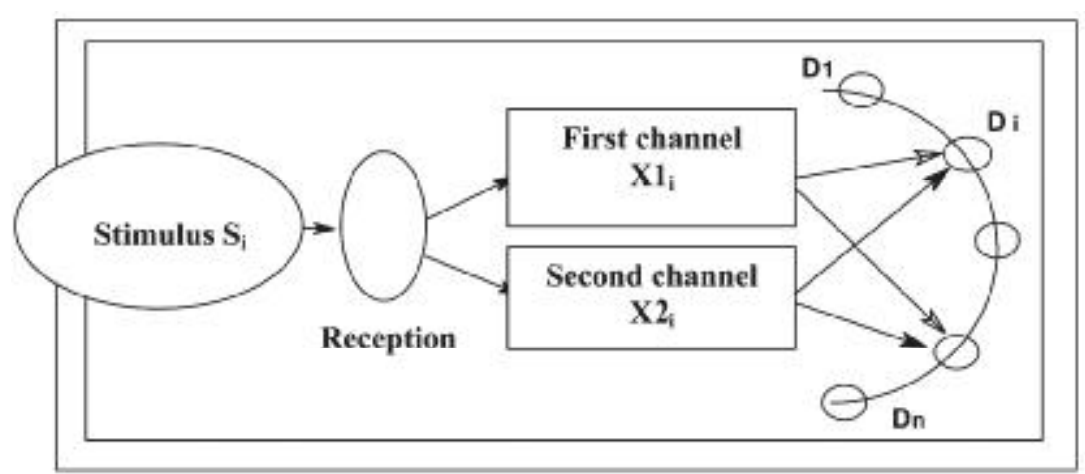

Figure 5. Schematic principal diagram of the 'dual neural module' of the visual system (for example, neural network, analyzing the energy parameters of stimulation). Stimulus $\left(\mathrm{S}_{\mathrm{i}}\right)$ represents the energy change in the environment. The receptors convert stimulus energy into electrical potentials triggering the activity of nerve cells in the first (X1) as well in the second channel (X2). Output signals of two channels $\left(\mathrm{X} 1_{\mathrm{i}}, \mathrm{X} 2_{\mathrm{i}}\right)$ are normalized and after normalization arrive simultaneously on synaptic inputs of detector neurons $D_{1}-D_{n}$. Then, in accordance with the theory of vector encoding, among a multitude of detectors $D_{1}-D_{n}$ there that detector is activated $\left(\mathrm{D}_{\mathrm{i}}\right)$, whose coefficients of synaptic transmission correspond to the incoming activities from two channels (Sokolov, 2003). In terms of the spherical model of stimuli discrimination, this means that the sum of products output activities of channels $\mathrm{X} 1$ and $\mathrm{X} 2$ and the corresponding coefficients of synaptic transmission in the detector $\mathrm{D}_{\mathrm{i}}$ will satisfy the spherical equation on the plane (Fomin et al., 1979). In this diagram the block 'reception' includes photoreceptors, and the proper 'channel module' is presented by retinal ganglion cells and cells in the lateral geniculate body. Detectors are presented by the neurons in visual cortex. Here, as we suppose, union dual modules to more complex multi-channel network starts. Most modern researchers linked the processes of categorization and the formation of complex visual images with the associative areas of parietooccipital and temporal cortex (for review see: Smith, 2005).

2004). The classical works of D. Hubel and T. Wiesel played a particularly important role in the development of this idea. In the visual cortex of the cat they found neurons detecting the orientation of lines, as well as neurons that are selective for stimulus figures that represent certain combinations of lines (Hubel \& Wiesel, 1962). The first type of neurons was called "detectors of simple attributes of a visual stimulus," and the sec- 
ond, "detectors of complex attributes." Subsequent studies have shown that these properties of the visual cortex occur in the most diverse types of higher vertebrates (Supin, 1981).

Our approach considers the cortical detectors of line orientation as an input structure which forms the basis for all the key elements of the next level of the visual system: the whole "configurational alphabet," including a line as a segment. The purpose of these structures is to gather information about the area of extended fluctuations of brightness, in the form of boundaries that separate one part of the visual field from another. That is, the emphasis is not on the line segment, but only on its orientation as a boundary element. This hypothesis allows us to explain the presence, in the primary projection area of the cortex of higher vertebrates, of a large number of detectors of line orientation, and to ascribe to them the role of "quasi-receptors" that perform the same input functions in the analysis of forms that retinal receptors fulfill in the retina's analysis of the spectral composition of radiation in the retina (Izmailov et al., 2004; Izmailov \& Zimachev, 2008; Izmailov et al., 2008). The composition of this multilevel "quasi-receptor" includes neurons of the retina and subcortical structures, which conduct a preliminary analysis of the spatial distribution of boundaries in the illumination level of the visual field. This activates detector neurons for lines of differing orientation.

Thus, in the framework of the above-mentioned three-stage neural network in the visual system that is responsible for "restoring" the configuration signal, the first stage is the activation of retinal photoreceptors and "quasi-receptors" - neuron-detectors of line orientation. At the second stage, a limited set of elements is drawn from these lines of orientation, including the line as a segment. In this case the value is not determined by the orientation of the line, but by the fact that, as a line segment, it is bounded at one or both ends, and is a full-fledged feature of a contour. This is the level at which basic or nodal elements of configuration are formed, to be used for subsequent construction of the integrated shape of the object. This function is associated with cortical neurons with complex and super complex receptive fields. Finally, at the third stage, the various nodal elements define configurations, which define the basic contours of objects in the visual field, just as the letters of the alphabet come together to form words (Izmailov \& Chernorizov, 2005). 


\section{The formation of basic units,}

\section{or modal elements of configuration}

To verify our proposal about the formation of basic elements of a two-channel-modular visual system, a series of studies was carried out on humans and animals, in which "complex" stimuli were formed from various combinations of "simple," one-dimensional stimuli, the perception of each of which is described by a two-dimensional spherical model of discrimination. Experiments with the discrimination of color stimuli may serve as the most obvious example of such combinations, with the stimuli changing their energy characteristics (intensity) and / or spectral composition (color). In extensive studies of human color vision using psychophysical methods (Izmailov \& Sokolov, 1978; 1991; Izmailov, 1980; 1982; 1995a; 1995b; Sokolov \& Izmailov, 1983; 1984; Paramei et al., 1991) and techniques of recording the evoked cortical potentials (Izmailov et al., 1989; 1998a; 2003; Izmailov \& Sokolov, 2004; Sokolov \& Izmailov, 2006; Chernorizov, 2008) as well as in studies of color vision in animals (Zimachev et al., 1991; Chernorizov, 1995b; 1999; Zimachev \& Chernorizov, 2001; Chernorizov \& Sokolov, 2001; Latanov et al., 1997; Izmailov et al., 2004; 2006; Izmailov \& Zimachev, 2008) it has been shown that the differentiation between achromatic and chromatic stimuli, taken separately, is accurately described by a two-dimensional spherical model of signal discrimination. The attributes of a two-channel neural network which is derived from this model are consistent with the electrophysiological characteristics of photoreceptors and color opponent neurons of the visual system. At the same time, experiments on stimulus differentiation, varying simultaneously in both brightness and color, have shown that the geometrical model of differentiation is a hypersphere in fourdimensional Euclidean space, which combines spherical models of separate discrimination of achromatic and chromatic stimuli, as two specific two-dimensional sub-spaces (Fig. 6). The three spherical coordinates of a stimulus point characterized such subjective color features as hue, saturation, and luminosity; and the four Cartesian coordinates of the stimulus points corresponded to two color opposing channels - "red / green" and "blue / yellow" - and two neural channels for brightness - "light" and "dark."

Similarly, experiments were conducted on the differentiation of stimuli, consisting of various combinations of "simple" configurational features, whose differentiation fits the structure of the spherical model 

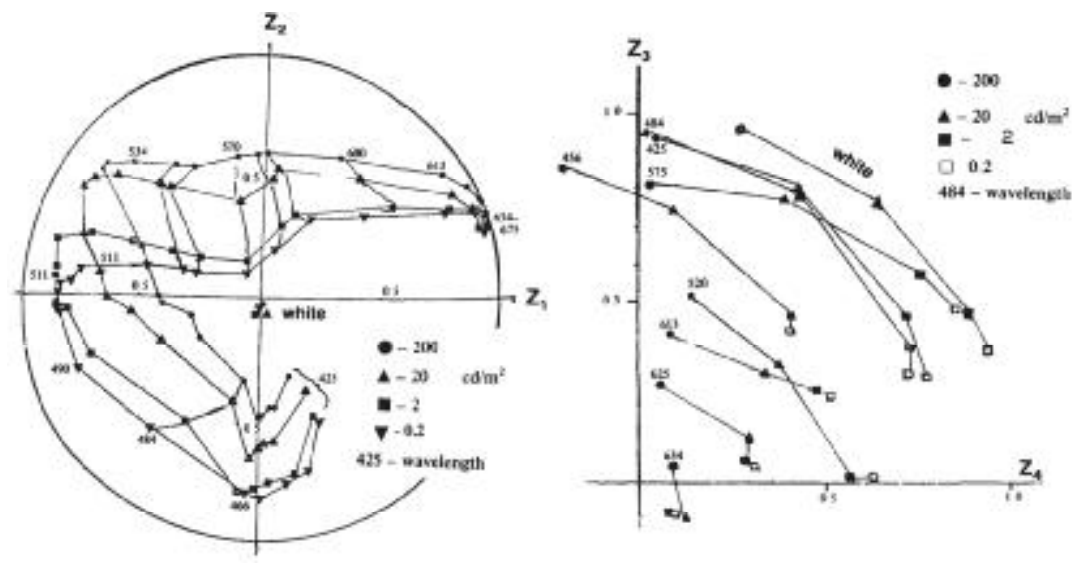

Figure 6. Color hypersphere in four-dimensional Euclidean space.

A. The projection of monochromatic radiations and white light, changing at 4 levels of brightness from 0.2 up to $200 \mathrm{~cd} / \mathrm{m}^{2}$, on plane $\mathrm{Z} 1 \mathrm{Z2}$ of four-dimensional color space. Each line connects the 25 monochromatic colors at the same level of brightness. Four points representing white stimuli of different luminance are located in the center of the plane. Values of wavelength $(\mathrm{nm})$ and brightness $\left(\mathrm{cd} / \mathrm{m}^{2}\right)$ are indicated in the figure near corresponding points.

B. The projection of eight spectral stimuli and white light, changing at 4 levels of brightness, on plane Z3Z4 of four-dimensional color space. Each line connects the points representing the same color at different levels of brightness. Values of wavelength (nm) and brightness $\left(\mathrm{cd} / \mathrm{m}^{2}\right)$ are indicated in the figure near corresponding points.

and the two-channel neural network. In particular, experiments involving the differentiation of two linear shapes, varied simultaneously as to size of angle and orientation, yielded a solution in the form of a spherical surface in three-dimensional Euclidean space (Izmailov et al., 2004a; Izmailov \& Chudina, 2005a). Two spherical coordinates of a stimulus point in this three-dimensional space corresponded to the subjective scale of orientation and size of angle, consistent with the data obtained in the separate scaling of these characteristics. But, unlike the four-dimensional color space, here, the combination of a pair of two-channel modules yielded a three-dimensional space, and, accordingly, three Cartesian coordinates were represented by a three-channel neural network. 
In this case, the result showed another kind of interaction between two two-channel source modules.

More interesting results were achieved in experiments on human differentiation of lines that varied both in intensity and orientation, i.e., with a combination of the energy and configurational stimulus characteristics (Izmailov et al., 2008; 2008a; Izmailov \& Edrenkin, in press). The geometrical model that most closely matched the initial matrix of pairwise differences between stimulus lines was a hypersphere in fourdimensional Euclidean space. From a formal point of view, this corresponded to a combination of two-channel modules of brightness and color, into a four-channel network of color vision. As in the color hypersphere, in the hypersphere that combines differentiation of brightness and orientation, two-dimensional subspaces corresponded to the spherical model of discrimination of these characteristics, analyzed separately. However, in this general spherical model, only two spherical coordinates of the three found their expression as psychophysical functions of the subjective attributes of brightness and orientation. The third spherical coordinate was uninterpreted and had no direct connection with any subjective stimulus characteristic. This distinguishes a hypersphere of brightness and orientation from a hypersphere of color, where the third spherical coordinate displayed an unambiguous association with color saturation. This means that here, as in the case of the neural network of color vision, the two-channel networks of brightness and orientation are also combined in a common four-channel network, but in a different way and with a different result.

Yet another difference between a "brightness / orientation hypersphere" and a color hypersphere turned out to be the nature of the interaction between two-channel modules. In a color hypersphere, the spherical coordinate characterizing the luminosity (subjective brightness), was dependent only on the brightness of the stimulus and did not depend on the stimulus's spectral composition, whereas the spherical coordinate characterizing the color of the stimulus depended both on the spectral composition and on the brightness of the stimulus (Izmailov, 1981; Wyszecki \& Stiles, 1982; Bimler, Paramei, \& Izmailov, 2009). In psychophysical terms, this means that the "color hypersphere" reproduces the Bezold-Bruecke visual phenomenon, whereby changes in perceived hue are associated with changes in brightness of the stimulus (Wyszecki \& Stiles, 1982; Bimler at al., 2009). And in neurophysiological terms that 
means the channels of achromatic modules have an inhibitory effect on the channels of the chromatic module, but not vice versa.

In the "brightness orientation hypersphere," the pattern is the opposite. The spherical coordinate characterizing the orientation of the stimulus line was only dependent on the slope of the line in the visual field, and not on the brightness of the stimulus, whereas the spherical coordinate characterizing the luminosity (subjective perception of brightness) of the stimulus depended on both the angle of inclination and the brightness of the stimulus (Izmailov \& Edrenkin, in press). This agrees with the data obtained in the study of the differentiation of lines of varying intensity and orientation, in the frog's visual system (Izmailov \& Zimachev, 2008). The results recorded by electroretinogram (ERG), using the method of instantaneous change of stimulus lines of varying brightness and orientation, indicate that the $\mathrm{V}$-shaped function of line orientation, which is built upon the amplitudes of the ERG b-wave, parallels the shifts in brightness of the line without changing its shape, whereas the brightness function detects nonlinear changes in brightness depending on the orientation of the stimulus. The retinal function of brightness for lines of different orientation revealed a striking similarity to analogous psychophysical brightness functions. In terms of the neurophysiology of the visual system, this means that the channels of an orientation module have an inhibitory effect on the channels of a brightness module, but not vice versa. In other words, when simultaneously changing both the energy and configurational characteristics of the stimulus, the configuration module takes priority over the brightness module.

The above data show that simple (one-dimensional) stimuli in different modalities are detected by the visual system using the same type of neural network, which we called a two-channel differentiation module. At the same time, the combination of two-channel modules in a network for detecting a more complex (multidimensional) stimulus occurs in different ways for the stimulus's energy parameters (wavelength and radiation intensity) and for configuration parameters (line orientation and the angle between two lines). Furthermore, the nature of the combination of an energy module (brightness) and a configuration module (orientation) into one common network also reveals its specificity. This calls into question the idea of the existence of a general principle of combination of individual modules into a more complex multi-channel network, as it is understood in the widespread hierarchical theories of visual perception. 
From our perspective, it is more reasonable to refer here to the principle of alphabetic language construction, and to assume that the basic elements (two-channel modules) of the visual system are combined into multi-channel networks analogous to the combination of letters into syllables, morphemes, and words (Izmailov \& Chernorizov, 2005). In speech, the combination of letters into syllables or of morphemes into words is determined by the meaning that is to be conveyed, rather than by physical characteristics or configurational characteristics of these elements. In precisely the same way, in visual perception, the combination of two-channel modules into a multi-channel network for complex stimulus detection is determined by the subject matter of the stimulus, and not by the physical and configurational characteristics of the light pattern. We should not be misled by the existence of rigid links, in the form of psychophysical functions, between features of light radiation and the subjective features whose terms (luminosity, color, shape, and movement) are used to describe and specify the phenomenology of visual perception.

Psychophysical functions express the specific character of the language of perception. In contrast to the language of speech, where meaning is completely independent of the physical medium of its speech elements, and exactly the same language can be used in an entirely different physical medium ("Saussure's postulate"), a visual language can only be realized by analysis of the parameters of electromagnetic radiation. Studies of the visual systems of all animals - both vertebrates and invertebrates - show that vision is based on the same photoreceptors ("Adrian's generalization") and, accordingly, no other physical effect except electromagnetic radiation in a very narrow spectral band $(380-700 \mathrm{~nm})$, can be perceived by the visual system. And this means that visual language is strictly associated with one unique physical medium.

On the one hand, this aspect of visual language makes the nature of visual perception difficult to understand, because it creates the illusion that perception is determined by stimulation, and that the goal of perception is to represent, as precisely and accurately as possible, a picture of the external environment (Bongard, 1967). This was proposed long ago by Aristotle, who asserted that to perceive means to know "what" and "where" (Izmailov \& Chernorizov, 2005). But taking an information approach instead, the purpose of perception is also to extract information from the environment, filtering it for its importance to the organ- 
ism, and transferring it to a storage center for later use in solving intellectual tasks (Neisser, 1976; Latanov et al., 1997). On the other hand, the psychophysical aspect of visual language facilitates the task of deciphering visual stimuli, because study of the properties of the medium (visual stimulation) and its relationship to the language structures (the subjective characteristics of perception) provides unique information about the nature of these structures. In particular, as shown in the data presented here, the identification of a two-channel module as the baseline element of visual language turned out to be possible only within the framework of the psychophysical methodology in visual perception studies. In just the same way, this methodology makes it possible to identify the next level of language structures - options for merging the baseline elements into the structural units of the visual language, equivalent to syllables or morphemes. All the results of the experiments examined here were obtained using the spherical model of stimulus discrimination. These studies allowed us to realize that classical psychophysics of perception has exhausted its potential, and that further progress in understanding the nature of perception requires that research include such features as "the meaning of the stimulus," i.e., the categorial characteristics of visual perception.

\section{Analysis of categorial characteristics of visual perception}

The advantage of the approach we propose is that it uses a common methodology for measuring the perceptual differences of not only energy and configurational stimulus features, but also of the categorial ones. In a special series of experiments, we used different types of categorial distinctions which are associated in different ways with changes in the configurational and energy stimulus variables.

Let us consider as an example the results of experiments with schematic representations of emotional expression in the human face (Izmailov et al., 1999; 2005b). In these experiments, oval-shaped images were used, with lines sketching the eyebrows, eyes, nose, and mouth. The face was given an emotional expression by curvature of the mouth, changing from zero (a horizontal line), up and down in increments of 14 degrees, and by the slant of the eyebrows, changing from zero up and down in increments of 6 degrees. In these experiments, test subjects were 
presented with pairs of 25 stimulus faces, and they rated the difference in emotional expressions between each pair of faces, on a scale from 1 to 9 (Izmailov et al., 1999). Test subjects were presented 50 pairs of faces in quick succession, and in response to each change, the evoked potential of differences (EPD) in the human visual and temporal cortex was recorded (Izmailov et al., 2005b). The interpeak amplitude of the P120-N180 and N180-P230 components, as well as the peak amplitude of N180 component, was used to measure the difference. As was shown in the work by Izmailov et al. (2001) the amplitude of these EPD components corresponds to the subjective estimates of interstimulus differences between the schematic faces. By combining all pairs of stimuli for each of the four leads, three matrices of interstimulus differences were obtained, expressed by the amplitudes of the three EPD components. The aim of this work was to build a geometrical model of the visual differentiation of schematic faces, both according to the amplitudes of evoked potential of differences registered in the human cortex in response to rapid-fire stimulus change, and according to the subjective evaluations of differences between emotional expressions of the same schematic faces. A detailed description of the formal and substantive criteria, on which the spherical model for distinguishing these stimuli was based, is presented in the work by Izmailov et al. (2005b). Here we consider only one aspect of the solution: the relationship between the configurational and categorial characteristics of visual perception.

The configurational attributes of the face are supplied by a pattern of lines representing the mouth and eyebrows, and the categorial ones by the emotional expressions (Ekman \& Frisan, 1978; Izmailov et al., 1999). Let us consider first the data obtained for subjective estimates of interstimulus differences. The system of spherical and Cartesian coordinates of the resultant four-dimensional space was analyzed according to the structure of the spherical model of stimulus discrimination and the two-channel neural network of the visual system. The analysis revealed that the four Cartesian coordinates are associated with perception of the orientation of the lines forming the eyebrows and mouth of the schematic faces. On this basis, it was concluded that the configurational attributes of the stimulus were detected by the four-channel neural network, composed of two-channel modules of line orientation. However, the emotional expression of the face takes up only two of the three spherical coordinates of the hypersphere. Thus, the first basic cat- 
egorial attribute of emotional expression, expressed in terms of six basic emotional categories (happiness, pleasure, surprise, fear, displeasure, disgust, anger), presented in the work by Ekman and Friesan (1978) was depicted in the form of the first spherical coordinate of the stimulus points (measured by the size of the horizontal angle in the X1X2 plane). Such mapping is consistent with the categorical structure of emotions in the form of the Schlossberg circle. By analogy with Newton's color circle for color tone, we have designated this attribute as emotional tone (Izmailov et al., 1999).

Another baseline characteristic of emotions, designated as emotional intensity, was expressed by the second spherical coordinate of the four-dimensional space, and measured by the vertical angle of the stimulus point, i.e., the angle between the $\mathrm{X} 3$ axis and the X1X2 plane. The model's third spherical coordinate had no apparent relationship to any expressive characteristics of the schematic face. Additional arguments in favor of this interpretation of the spherical model of schematic faces follow from the EDP analysis, recorded during the rapid substitution of schematic faces. The model built using EDP analysis has the form of a four-dimensional sphere with the same properties of spherical and Cartesian coordinates as the model constructed from psychophysical data (Izmailov et al., 1999).

The main conclusion to be drawn from these experiments is that the geometric representation of categorial attributes of the stimulus has a simpler, less rigid structure than the representation of configurational attributes of the stimulus, although it is based on the same mechanism of two-channel modules of the visual system. On the other hand, the EDP analysis shows that the configurational and categorial attributes of complex stimuli (schematic faces) are detected simultaneously, not sequentially. This demonstrates the essential independence of the categorial description of stimuli from the configurational structure of these stimuli. The transition from the configurational attributes of the stimulus to its categorial properties can be viewed as a transition from a multidimensional metric space (a hypersphere) to two-dimensional topological mapping. Similarly, we have obtained additional confirmation of these findings by studying the visual perception of words denoting colors and emotions (Izmailov et al., 2008b). 


\section{References}

Biederman, I. (1995). Higher-Level Vision. In D.N. Osherson, S.M. Kosslyn, \& M. Hollerbach (Eds.), Visual Cognition and Action. Cambridge: MA MIT Press.

Bimler, D.L., Paramei, G.V., \& Izmailov, Ch.A. (2009). Hue and Saturation Shifts from Spatially Induced Blackness. J. Opt. Soc. Am., 26 (1), 163-172.

Bongard, M.M. (1955). Kolorimetriâ na životnyh [Colorimetry on Animals]. DAN SSSR, 103 (2), 239-242.

Bongard, M.M. (1967). Problema uznavaniâ [Recognition Problem]. Moskva: Nauka.

Chernorizov, A.M. (1995b). Cvetovoe zrenie ryby kak model' cvetovogo zreniâ čeloveka [Color Vision of Fish as a Model of Human Color Vision]. Vestnik Moskovskogo universiteta. Seriâ 14 "Psihologiâ," 4, 35-42.

Chernorizov, A.M. (1995a). Èlektroretinogramma temnoadaptirovannogo intaktnogo karpa Carpio Cyprinus L. na zamenu cvetov [Electroretionogram of Intact DarkAdapted Carp Carpio Cyprinus L. Evoked by Color Change]. Žurnal vysšej nervnoj deâtel'nosti, 45 (1), 155-162.

Chernorizov, A.M. (1999). Nejronnye mehanizmy cvetovogo zreniâ [Neural Mechanisms of Color Vision] (Doctor of Sciences dissertation). Moscow.

Chernorizov, A.M. (2006). Èksperimental'noe issledovanie i modelirovanie nejronnyh mehanizmov ahromatičeskogo zreniâ vinogradnoj ulitki Helix lucorum L. [Experimental Research and Modeling of Neuronal Mechanisms of Achromatic Vision in Snail Helix lucorum L.]. Nejrokomp'ûtery: razrabotka i primenenie, 4-5, 78-89.

Chernorizov, A.M. (2006a). Vector Encoding of Light Intensity in Neuronal Nets of Snail Eye. International Journal of Psychophysiology, 61 (3), 307-308.

Chernorizov, A.M. (2008). Vector Encoding of Color in Visual System of Human and Animals. International Journal of Psychophysiology, 69 (3), 173-174.

Chernorizov, A.M., Shekhter, E.D., Arakelov, G.G., \& Zimachev, M.M. (1994). The Vision of the Snail: The Spectral Sensitivity of the Dark-Adapted Eye. Neuroscience \& Behavioral Physiology, 24 (1), 59-62.

Chernorizov, A.M., \& Sokolov, E.N. (2001). Vektornoe kodirovanie cveta v sloe bipolârnyh kletok setčatki karpa [Vector Encoding of Color in Bipolar Cells of Carp Retina]. Vestnik Moskovskogo universiteta. Seriâ 14 "Psihologiâ," 1, 12-35.

Chernorizov, A.M., Zimachev, M.M., Shekhter, E.D., \& Garusev, A.V. (2007). Mehanizmy ahromatičeskogo zreniâ mollûska Helix lucorum L.: vnutrikletočnoe issledovanie svetočuvstvitel'nyh kletok setčatki [Mechanisms of Achromatic Vision in Snail Helix lucorum L.: Intracellular Study of Light-Sensitive Cells in Retina]. Žurnal vysšej nervnoj deâtel'nosti, 57 (1), 121-127. 
Chernorizov, A.M., \& Sokolov, E.N. (2010). Mechanisms of Achromatic Vision in Invertebrates and Vertebrates: A Comparative Study. The Spanish Journal of Psychology, 13 (1), 18-29.

Ekman, P., \& Friesan, W.V. (1978). Facial Action Coding System. Manual (pp. 15-120). Palo Alto: Consult. Psychol. Press.

Estevez, O., Spekreijse, H. (1982). The "Silent Substitution" Method in Visual Research. Vision Research, 22 (6), 681-691.

Fomin, S.V., Sokolov, E.N., \& Vaitkyavichus, G.G. (1979). Iskusstvennye organy čuvstv [Artificial Sensory Systems]. Moscow: Nauka.

Gibson, J.J. (1979). An Ecological Approach to Visual Perception. Boston: Houghton Mifflin.

Gregory, R.L. (1970). The Intelligent Eye. New York: McGraw-Hill.

Hartridge, H. (1950). Recent Advances in the Physiology of Vision. London: Churchill.

Heggelund, P. (1974). Achromatic Color Vision. I. Perceptive Variables of Achromatic Colors. Vision Res., 14, 1071-1078.

Hess, R.F., \& Baker, C.L. (1984). Human Pattern-Evoked Electroretinogram. J. Neurophysiol., 51, 939-951.

Hubel, D.N., \& Wiesel, T.N. (1962). Receptive Fields, Binocular Integration and Functional Architecture in the Cat's Visual Cortex. J. Physiology, 160, 106-154.

Ivanitsky, A.M., Strelets, V.B., \& Korsakov, I.A. (1984). Informacionnye processy mozga i psihičeskaâ deâtel'nost' [Informational Processes in the Brain and Psychological Activity]. Moscow: Nauka.

Izmailov, Ch.A. (1980). Sferičeskâ̂ model' cvetorazličeniâ [Spherical Model of Color Discrimination]. Moscow: MGU.

Izmailov, Ch.A. (1981). Mnogomernoe škalirovanie ahromatičeskoj sostavlâûsejej cveta [Multidimensional Scaling of Achromatic Components of Color]. In B.F. Lomov et al. (Eds.), Normativnye i deskriptivnye modeli prinâtiâ rešeniâ. Materialy sovetskoamerikanskogo seminara (pp. 98-110). Moscow: Nauka.

Izmailov, Ch.A. (1982). Uniform Color Space and Multidimensional Scaling (MDS). In H.G. Geissler \& F. Petsold (Eds.), Psychophysical Judgement and the Process of Perception (pp. 52-62). Berlin: VEB Deutcher Verlag der Wissenschaften.

Izmailov, Ch.A. (1995). Spherical Model of Discrimination of Self-Luminous and Surface Colors. In R.D. Luce, M.D. D’Zmura, D. Hoffman, G.J. Iverson, \& A.K. Romney (Eds.), Geometric Representations of Perceptual Phenomena (pp. 153-168). Mahwah, New Jersey, Hove UK: Lawrence Erlbaum Associates Publishers.

Izmailov, Ch.A., \& Sokolov, E.N. (1978). Metričeskie harakteristiki sferičeskoj modeli cvetorazličeniâ [Metric Characteristics of Spherical Model of Color Discrimination]. Vestnik Moskovskogo universiteta. Seriâ 14 "Psihologiâ," 2, 47-61. 
Izmailov, Ch.A., Sokolov, E.N., \& Chernorizov, A.M. (1989). Psihofiziologiâ cvetovogo zreniâ [Psychophysiology of Color Vision]. Moscow: MGU.

Izmailov, Ch.A., \& Sokolov, E.N. (1990). Multidimensional Scaling of Lines and Angles Discrimination. In H.G. Geissler (Ed.), Psychophysical Explorations of Mental Structures (pp. 181-189). Toronto-Bern-Stuttgart: Hogrefe-Huber Publishers.

Izmailov, Ch.A., \& Sokolov, E.N. (1991). Spherical Model of Color and Brightness Discrimination. Psychological Science, 2, 249-259.

Izmailov, Ch.A., Isaichev, S.A., \& Shekhter, E.D. (1998). Dvuhkanal'naâ model' različeniâ signalov v sensornyh sistemah [Two-Channel Model of Signal Discrimination in Sensory Systems]. Vestnik Moskovskogo universiteta. Seriâ 14 "Psihologiâ," 3, 29-40.

Izmailov, Ch.A., Isaichev, S.A., Korshunova, S.G., \& Sokolov, E.N. (1998a). Cvetovoj i ârkostnyj komponenty zritel'nyh vyzvannyh potencialov u čeloveka [Color and Brightness Components of Human Visual Evoked Potentials]. Žurnal vysšej nervnoj deâtel'nosti, 48 (5), 777-787.

Izmailov, Ch.A., Korshunova, S.G., \& Sokolov, E.N. (1999). Sferičeskaâ model' različeniâ èmocional'nyh vyraženij shematičeskogo lica [Spherical Model of Discrimination of Emotional Expressions of Schematically Represented Faces]. Žurnal vysšej nervnoj deâtel'nosti, 49 (2), 186-199.

Izmailov, Ch.A., Korshunova, S.G., \& Sokolov, E.N. (2001). Relationship between Visual Evoked Potentials and Subjective Differences between Emotional Expressions in "Face Diagrams." Neuroscience \& Behavioral Physiology, 31, 529-538.

Izmailov, Ch.A., Sokolov, E.N., \& Korshunova, S.G. (2003). Cvetovoe prostranstvo čeloveka, osnovannoe na dannyh o korkovyh vyzvannyh potencialah [Human Color Space Based on Evoked Potentials of Cortex]. Sensornye sistemy, 17 (1), 32-44.

Izmailov, Ch.A., \& Sokolov, E.N. (2004). Subjective and Objective Scaling of Large Color Differences. In C. Kaernbach, E. Schroger, \& H. Muller (Eds.), Psychophysics Beyond Sensation. Laws and Invariants of Human Cognition (pp. 27-42). Mahwah, New Jarsy, London: Lawrence Erlbaum Associates.

Izmailov, Ch.A., Sokolov, E.N., Korshunova, S.G., \& Chudina, Yu.A. (2004a). Geometričeskaâ model' različeniâ orientacii linii, osnovannaâ na sub"ektivnyh ocenkah i zritel'nyh vyzvannyh potencialah [Geometrical Model for Discrimination of Lines Orientation Based on Subjective Evaluations and Visual Evoked Potentials]. Žurnal vysšej nervnoj deâtel'nosti, 54 (2), 267-279.

Izmailov, Ch.A., \& Chernorizov, A.M. (2005). Âzyk vospriâtiâ i mozg [Language of Perception and Brain]. Psihologiâ. Žurnal Vysšej školy èkonomiki, 2 (4), 22-52.

Izmailov, Ch.A., \& Chudina, Yu.A. (2005a). Konfiguracionnye i kategorial'nye harakteristiki zritel'nogo vo spriâtiâ shematičeskih figur [Configuration and Categorical Characteristics of Visual Perception of Schematic Figures]. Vestnik RUDN, 2, 27-41. 
Izmailov, Ch.A., Korshunova, S.G., \& Sokolov, E.N. (2005b). Multidimensional Scaling of Schematically Represented Faces Based on Dissimilarity Estimates and Evoked Potentials of Differences (EPD) Amplitudes. The Spanish Journal of Psychology, 8 (2), 119-133.

Izmailov, Ch.A., Zimachev, M.M., Sokolov, E.N., \& Chernorizov, A.M. (2006). Dvuhkanal'naâ model' ahromatičeskogo zreniâ lâguški [Two-Channel Model of Frog Achromatic Vision]. Sensornye sistemy, 20 (1), 1-11.

Izmailov, Ch.A., \& Zimachev, M.M. (2008). Detection of Bimodal Stimuli in the Frog Retina. Neurosci. Behav Physiol., 38 (2), 103-114.

Izmailov, Ch.A., Sokolov, E.N., \& Edrenkin, I.V. (2008a). Integrirovaniâ prostyh priznakov stimula v nejronnyh setâh zritel'noj sistemy [Integration of Simple Features of Stimulus in Neuronal Nets of Visual System]. Nejrokomp'ûtery: razrabotka i primenenie, 3-4, 43-55.

Izmailov, Ch.A., Korshunova, S.G., \& Sokolov, E.N. (2008b). The Semantic Component of the Evoked Potential of Differentiation. The Spanish Journal of Psychology, 11 (1), 321-340.

Izmailov, Ch.A., \& Edrenkin, I.V. (in press). Različenie bimodal'nyh stimulov zritel'noj sistemoj [Discrimination of Bimodal Stimuli in Visual System]. In G. Golovina (Ed.), Matematičeskaâ psihologiâ v Rossii. Moscow: IP RAN.

Julesz, B. (1984). A Brief Outline of Texton Theory of Human Vision. Trends in Neuroscience, 7, 41-45.

Jung, R. (1973). Visual Perception and Neurophysiology. In R. Jung \& H. Autrum (Eds.), Handbook of Sensory Physiology. V. 7/3. Central Processing of Visual Information. Part A. (pp. 1-153). Heidelberg, Berlin: Springer-Verlag.

Kruskal, J.B. (1964). Multidimensional Scaling by Optimizing Goodness of Fit to a Nonmetric Hypothesis. Psychometrika, 29, 1-27.

Latanov, A.V., Leonova, A.Yu., Evtikhin, D.V., \& Sokolov, E.N. (1997). Sravnitel'naâ nejrobiologiâ cvetovogo zreniâ čeloveka i životnyh [Comparative Neurobiology of Color Vision of Human and Animals]. Žurnal vyšsej nervnoj deâtelnosti, 47 (2), 308-320.

Lindsay, P.H., \& Norman, D.A. (1972). Human Information Processing. New York, London: Acad. Press.

Maffei, L., Fiorentini, A., Bisti, S., \& Hollander, H. (1985). Pattern ERG in the Monkey after Section of the Optic Nerve. Exp Brain Res., 59 (2), 423-430.

Maffei, L., \& Fiorentini, A. (1990). Pattern Visual Evoked Potentials and Electroretinograms in Man and Animals. In J.E. Desmedi (Ed.), Visual Evoked Potentials (pp. 25-33). New York: Elsever Sci. Publ.

Neisser, U. (1976). Cognition and Reality. San Francisco: Freeman WH and company.

Paramei, G.V., Izmailov, Ch.A., \& Sokolov, E.N. (1991). Multidimensional Scaling of Large Chromatic Differences by Normal and Color-Deficient Subjects. Psychological Science, 2, 244-248. 
Paramei, G.V., \& Chernorizov, A.M. (1991). Sferičeskaâ teoriâ vospriâtiâa: proverka metodami psihofiziki i nejrofiziologii [Spherical Model of Perception: Verification by Methods of Psychophysics and Neurophysiology]. Žurnal vysšej nervnoj deâtelnosti, 41 (4), 627-634.

Paulus, W.M., Homberg, V., Cuninghum, K., Halliday, A., \& Ronde, N. (1984). Color and Brightness Components of Foveal Visual Evoked Potentials in Man. Electroencephalograhy and Clinic. Neurophysiology, 58, 107-119.

Poggio, G.F., Baker, F.N, Lamarre, Y., \& Sanseverino, E.R. (1969). Afferent Inhibition at Input to Visual Cortex of the Cat. JOSA, 32, 892-915.

Polyansky, V.B., Sokolov, E.N., \& Evtikhin, D.V. (2000). Rekonstrukciâ perceptivnogo prostranstva ârkosti i cveta na osnove vyzvannyh potencialov $i$ ih sravnenie $s$ dannymi povedenčeskih opytov [Reconstruction of Color and Brightness Perceptual Spaces Based on Evoked Potentials and Behavioral Experiments]. Žurnal vysšej nervnoj deâtel'nosti, 50 (5), 843-854.

Polyansky, V.B., Alymkulov, D.E., Sokolov, E.N., \& Radzievskaya, M.G. (2008). Otraženie v vyzvannyh potencialah zritel'noj kory krolika izmenenij v orientacii i intensivnosti linij [Representation of Changing Orientation and Intensity of Lines in Evoked Potentials of Rabbit Visual Cortex]. Žurnal vysšej nervnoj deâtelnosti, 58 (6), 688-699.

Shapley, R. (1990). Visual Sensitivity and Parallel Retinocortical Channels. Annu. Rev. of Psychol., 41, 635-658.

Shelepin, Yu.G. (1981). Orientacionnaâ izbiratel'nost' i prostranstvenno-častotnye harakteristiki receptivnyh polej nejronov zritel'noj kory koški [Orientational Selectivity and Spatial-Frequency Characteristics of Receptive Fields of Neurons in Cat Visual Cortex]. Nejrofiziologiâ, 13 (3), 227-232.

Shepard, R.N. (1962). The Analysis of Proximities: Multidimensional Scaling with an Unknown Distance Function. Psychometrika, 27, 125-140, 219-246.

Shepard, R.N., \& Carroll, J.D. (1966). Parametric Representation of Nonlinear Data Structures. In P.R. Krishnaiah (Ed.). Multivariate analysis (pp. 561-592). New York: Acad. Press.

Shepard, R.N. (1987). Towards a Universal Law of Generalization for Psychological Space. Science, 237, 1317-1323.

Shevelev, I.A., Lazareva, N.A., \& Sharaev, G.A. (1999). Interrelation of Tuning Characteristics to Bar, Cross and Corner in Striate Neurons. Neuroscience, 88, 17-25.

Shvyrkov, V.B., \& Aleksandrov, Yu.I. (1973). Obrabotka informacii, povedenčeskij akt i korkovye nejrony [Analysis of Information, Behavioral Act and Cortex Neurons]. DAN SSSR, 212 (4), 1021-1024.

Sokolov, E.N. (1980). Principles of Psychophysiology. Soviet Psychology, 18, 69-82. 
Sokolov, E.N. (1986). Research Strategy in Psychophysiology. In R.B. Marcus, G.Y.W Dorn, \& P. Weingartner (Eds.). Logic, Methodology and Philosophy of Science (pp. 495-502). Amsterdam: North-Holland.

Sokolov, E.N. (2003). Vospriâtie i uslovnyj refleks. Novyj vzglâd [Perception and Conditioned Reflex. New approach]. Moscow: UMK "Psihologiâ," MPSI.

Sokolov, E.N., \& Izmailov, Ch.A. (1983). Conceptual Reflex Arc and Color Vision. In H.G. Geissler (Ed.), Modern Issues of Perception (pp. 192-216). Berlin: VEB Deutscher Verlag der Wissen; Amsterdem: North Holland Publ. Comp.

Sokolov, E.N., \& Izmailov, Ch.A. (1984). Cvetovoe zrenie [Color Vision]. Moscow: MGU.

Sokolov, E.N., \& Izmailov, Ch.A. (1988). Trehstadijnaâ model' cvetovogo zreniâ [Three-Stage Model of Color Vision]. Sensornye sistemy, 2 (4), 314-320.

Sokolov, E.N., \& Izmailov, Ch.A. (2006). Vyzvannye potencialy v sferičeskoj modeli kognitivnyh processov [Evoked Potentials at the Frame of Spherical Model of Cognitive Processes]. Nejrokomp'ûtery: razrabotka i primenenie, 4-5, 90-105.

Stevens, S.S. (1961). To Honor Fechner and Repeal his Law. Science, 133, 80-86.

Supin, A.Ya. (1981). Nejrofiziologiâa zreniâ mlekopitẩisih [Neurophysiology of Mammals Vision]. Moscow: Nauka.

Torgerson, W.S. (1958). Theory and Method of Scaling. New York: Wiley.

Winston, P.P. (1978). Komp'ûternoe zrenie [Computer Vision]. In P.P. Winston (Ed.), Psihologiâ mašinnogo zreniâ. Moscow: Mir.

Wyszecki, G., \& Stiles, W.S. (1982). Color Science: Concepts and Methods, Quantitative Data and Formulae (2nd ed.). New York: Wiley.

Zimachev, M.M., Shekhter, E.D., Sokolov, E.N., \& Izmailov, Ch.A. (1986). Hromatičeskaâ sostavlâûŝâa èlektroretinogrammy lâguški [Chromatic Component of Frog Electroretinogram]. Žurnal vysšej nervnoj deâtelnosti, 36 (6), 1100-1107.

Zimachev, M.M., Shekhter, E.D., Sokolov, E.N., Naatanen, R., Niman, G., \& Izmailov, Ch.A. (1991). Različenie cvetovyh signalov setčatkoj lâguški [Discrimination of Color Signals by Frog’s Eye]. Žurnal vyš̌ej nervnoj deâtelnosti, 41 (3), 518-527.

Zimachev, M.M., \& Chernorizov, A.M. (2001). Struktura prostranstva cvetorazličeniâ lâguški v raznye periody eë sezonnoj aktivnosti [Structure of Frog Color Space for Different Periods of its Seasonal Activity]. Vestnik Moskovskogo universiteta. Seriâ 14 "Psihologiâ," 2, 12-32. 